\title{
How Myanmar Female Workers Negotiate In Their Workplace At Chiang Rai, Thailand
}

\author{
Tin Moe Yi \\ Department of English, \\ Loikaw University, Kayah State, Myanmar
}

\begin{abstract}
In Thailand, there are many migrants from Myanmar who distributed in five top sectors which are agriculture, construction, fishery related, agriculture related and service. The total number of Myanmar migrant workers in Thailand today is estimated to be about between 1,500,000 and 1,600,000 with over 100,000 women from Myanmar employed as domestic workers. In Myanmar, in the political affairs, women are effectively excluded from participating in the negotiations for peace. In this article, the researcher explored how woman workers negotiate at their workplace. The present study was based on the case study of Myanmar female workers' attitudes towards whether and how they negotiated in their workplace. To assess their attitude, three categories focused by Weaver [5] were applied to get the information. It is observed that most of the female workers had the same attitude that they did not ask any more to their employer and did not want to negotiate because some were satisfied with their jobs as their head solved their problems on behalf of them and some were lack of confidence. The women are weak, emotional and submissive so they might not be successful negotiators.
\end{abstract}

Keywords: female workers; migrants; negotiate; workplace.

INTRODUCTION

According to Awatsaya, 2004 cited in Doncha-um, [2], over the past two decades, Thailand has experienced a large scale immigration of illegal migrants coming from neighboring countries such as Myanmar, Cambodia and Lao. The total number of Myanmar migrant workers in Thailand today is estimated to be about between 1,500,000 and 1,600,000 with over 100,000 women from Myanmar employed as domestic workers.

In Myanmar, in the political affairs, women are effectively excluded from participating in the negotiations for peace. Less than handful women have been part of the official talks held between the State and the armed groups. They have been also effectively excluded from participating in local and national decision-making processes and from negotiation. Naw May Oo (KNU, 2012 cited in Jenny Hedstrom, [3] said that there was no engagement or attempt to engage with women and gender issues. It is a little difficult to talk about women's participation in the process of negotiation and in politics because in Myanmar culture and tradition, the men feel they have to do these things which are their duty. In Myanmar, most of the women keep their households by looking after their children, cooking meals for the family, keeping the house clean and doing the odd jobs in the house. Therefore, in this research, the researcher explored how woman workers negotiate at their workplace. At the current time some women can work the same level of men. However, there is also gender discrimination between male and female.

Collins, 2009 cited in Weaver. D.E.201 [5] said that the women do more than their parents as well as the children. According to the Bureau of Labor Statics 2009 cited in Weaver, D. E. [5] 
women have earned less than what men earn, in jobs from the high end of the pay scale to the lowest end, for decades. The purpose of this study was to investigate whether and how Myanmar female workers employed in Chiang Rai, Northern Thailand, negotiated on their own behalf in the workplace. This qualitative study was based on interviews with 10 women in construction and domestic service fields. This study focuses on women workers in the workplace.

\section{GENDER DIFFERENCES}

According to Ridgeway (2001) cited in Paddock, E. L et al. [4] status is a sign of greater social significance and general competence. Status is defined by the extent to which an individual is respected by others (Magee and Galinsky, 2008 cited in Paddock, E. L et al. (2011) [4]. Status is distinct from power, which is an individual's control of resources and often conferred by the roles an individual holds, including societal and organizational roles.

When men and women have equal power in negotiation (e.g. their alternatives to the potential negotiated agreement are equal), they are equally effective at leveraging their negotiation power (Kray, Reb, Galinsky and Thompson, 4004 cited in Paddock, E. L et al. [4]. Men and women typically differ in their status and power both generally and within negotiations specially. In general status differs based on gender, with individuals associating greater trait competence with men than women, Ridgeway, 2001cited in Paddock, E. L et al. [4]. Likewise, within negotiations traits typically associated with men and not with women are related to being a competent negotiator.

Gender stereotypes reflect the gender roles. Men are rational, assertive, and highly protective of their own interests, Williams and Best, cited in Paddock, E. L et al. [4] . In contrast, women are passive, emotional and accommodation of others' needs. Women world are underrepresented within upper-management. Further, gender stereotypes are consistent across nations , Williams and Best, 1982 cited in Paddock, E. L et al. [4] . Stereotypic traits associated with men are also associated with being an effective negotiator. Men are often perceived as better negotiators than women. Due to Kray and Thompson, 2005 cited in Paddock, E. L et al. [4], attributes associated with being an effective negotiator include "strong", "dominant", "assertive, and "rational' that are associated with males. In contrast, attributes associated with being a weak negotiator include "weak", "submissive", "accommodating", and "emotional" that is associated with females. In negotiations, men tend to set higher goals than women. Bowles and colleagues, 2005 cited in Paddock, E. L et al. [4] found that male buyers set goals that were 9.8\% higher than women's. Setting high goals in negotiation is very important because goals mediate the relationship between stereotype activation and performance. Activated stereotypes hurt women's negotiation performance by lowering the goals set by women (Kray et al., 2002cited in Paddock, E. L et al. (2011) [4]. Negotiators focused on a high goal on a high goal make higher first offers and achieve better outcomes, Galinsky and Mussweiler, 2001 cited in Paddock, E. L et al. [4].

\section{GENDER EFFECTS IN NEGOTIATION}

According to Paddock, E. L et al. [4], there are several strategies to mitigate gender effects in negotiation. These include negotiations making sure: they ask for what they want, taking care to avoid self-handicapping behaviors and reacting to negative and focusing on positive stereotype elements with negotiations.

\section{Ask for whey they want:}

Women may avoid participating in negotiations. On the other hand, some studies show that there are no differences between women and men in willingness to negotiate for salary 
increases, while some evidence indicates women ask less often. Within compensation negotiations, it may be women ask, but often ask for different things: women are more likely to ask for job components including work and travel schedules, notably factors that relate more closely than some other job components to household responsibilities, Bohnet and Greig, 2007 cited in Paddock, E. L et al. [4]. According to Bernard, 2010, when a woman negotiates persuasively for higher compensation, she clears the path for other women to follow.

\section{Taking care to avoid self-handicapping behaviours:}

Rather than try but poor results, negatively stereotyped individuals may put forth little effort, providing themselves with a more palatable explanation for their poor performance, Keller, 2002 cited in Paddock, E. L et al. [4]. Preparation is one critical aspect of negotiation. The ongoing development of alternatives provides negotiators with a stronger best alternatives to a negotiated agreement (BATNA). Generation of alternatives may help in part because they allow women to feel less dependent on the other party and thus increasing their willingness to walk away from the table, Kray, 2007 cited in Paddock, E. L et al. (2011) [4]. Once an individual has entered into a negotiation, she should avoid falling into the trap of self-handicapping. By directing her efforts towards careful preparation and ongoing generation of alternatives, she will at best achieve high negotiation outcomes and at worst gain practice, which will make her a better negotiator.

\section{Reacting to the negative and focusing on the positive stereotype elements}

Women's greater concern with their counterparts may mean women are less biased by their own goals than men. In contrast, men's greater pragmatism, evidenced by more egocentrism and instrumentalism, results in more leniency in judging ethically ambiguous actions than are women.. Focusing on the positive aspects of gender stereotypes helps the women to build confidence, and thus improving performance, for men and women the same.

\section{THE HISTORY OF MYANMAR COMING TO THAILAND}

According to Chantavanich, S. [1], cross-border migrants from Myanmar to Thailand have a long history spanning many decades. In the past, ethnic groups who lived along the ThaiMyanmar borders, especially the Karen, the Mon and the Shan, came across the borders to visit friends, buy goods or seek healthcare services in the area regularly. After 1980, a significant number of asylum-seekers from Myanmar started to enter Thailand to take refuge. The Thai government agreed to host a big number of political asylum-seekers in nine temporary shelters in four provinces at the border areas. Another way of migrants arrived is for economic reasons. They were both ethnic and Bamar people. Since 1992, Thailand has allowed officially for the entrance of migrants from Myanmar into Thailand's labour market.

The local labour market in Thailand needs unskilled workers in many sectors, including agriculture, manufacturing and some service work, especially domestic and construction works. Many Thai workers do not want to work in such sectors. Moreover, the wages in Thailand are higher than what workers can find in Myanmar. Due to the slow economic growth and much unemployment in Myanmar, both Bamar and ethnic groups come to Thailand for their job opportunities and higher wages. At the present time, the number of migrant workers from Myanmar has increases more and more before.

Migrant workers are mainly hired in the sectors of agriculture, construction, fishery and domestic work. Although the Thai government announced that only unskilled migrant workers or can be employed, a few skilled workers like teachers, university teachers and health workers from Myanmar are also employed in Thailand. The following figure shows the 
numbers of migrants from worked in five top sectors, Thailand. This figure is according to 2011 survey in Thailand.

\section{Chart 1 Distribution of migrant from Myanmar in 5 top sectors}

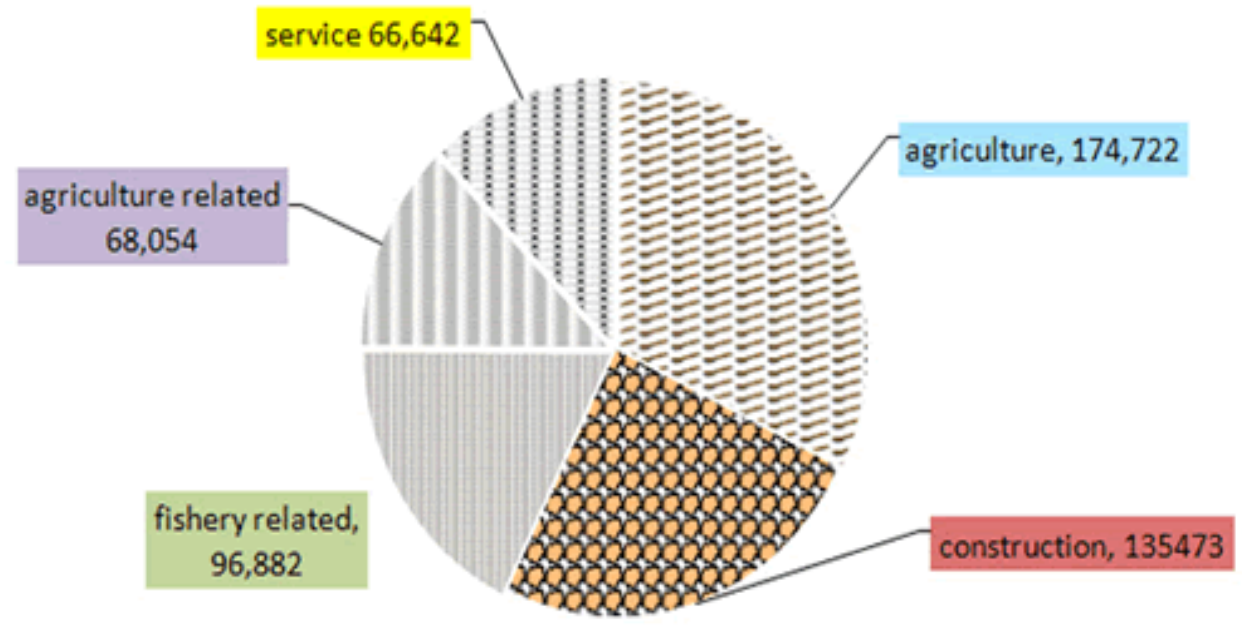

Source: MOL, Thailand, 2011

Chart 1. Distribution of migrant from Myanmar in 5 sectors

Among the skills that migrant workers learned spontaneous while working in Thailand, construction, agriculture and some manufacturing skills are the most relevant to economic reform in Myanmar.

\section{METHODOLOGY}

The researcher follows the categories to gather the information focused by Weaver, D.E. [5] to explore how the women workers learn to speak up and negotiate themselves in the workplace - demographic, contextual and perceptual. The researcher also follows these categories.

\section{Demographic Information}

The important information is collected from each participants in the interview. The researcher gathered the information on demographic inventory form, including data on age, ethnicity, race, profession, educational experiences and career path. It contains 1) family structure in family of origin, 2) location of family residence in the participant's early childhood years, 3) educational experiences, 4) relationship/ martial status during their adulthood and currently, 5) numbers and ages of any children, 6) responsibilities for caring for other individuals such as elderly parents, and 7) career path.

\section{Contextual Information}

Contextual information about each participant's current place of work and current relationship/ marital status as a caretaker of either children or elderly parents was gathered to provide richer understanding of the responses to the interviews.

\section{Perceptual Information}

The researcher went to the workplace or to their resident place to talk with the participants individually an hour per a person in an informal, open-ended, yet structured interview. After each interview, the researcher wrote up notes about her perceptions of the participants' comments, behaviours, emotions or other issues that arose the interviews. 
The researcher used a qualitative study design in order to gather women's self-reports on their behaviors when they needed to negotiate on their own behalf. The participants were the female workers the ages of approximately 20 to 40 who some had at least three years of work experience and some has a few months. These workers were selected based on their willingness to be interviewed.

Boyatis, 1982 cited in Weaver. D. E [5] defined the negotiation competence as a mix of skills, knowledge, and attitudes. The researcher did not judge the study participants on their level of negotiation competence. This study was not intended to distinguish the individuals who were the best at negotiating among the participants. This study focuses on how Myanmar women worker negotiate at their workplace in Chiang Rai.

\section{THE PRESENT STUDY}

The present study was based on the case study of Myanmar female workers' attitudes towards whether and how they negotiated in their workplace. There are many workers who work in different sectors in Chiang Rai, Northern Thailand. For this paper, only the female workers were focused and ten female workers from two sectors were selected although many are interviewed. Three were from domestic work and seven were from construction Co Ltd. They all are not graduated persons and only workers. In that study, they were interviewed in Myanmar and translated into English. They all are Myanmar Buddhists. The overall aim was to tell each female worker's story and their attitudes towards speaking up and negotiation at their workplace and the relationship between the employees and the employers.

The participants were interviewed and the researcher also went to their residence and workplace in Chiang Rai, Thailand to collect the real data. It is observed that most of the workers had the same attitude that they did not ask any more to their employer and did not want to negotiate.

\section{Case (1): Daw (Mrs) Thinn Gyaing}

She is 35 years old. She works in the construction as a mason in Chiang Rai. She has never worked before this work. She has experienced this work for six years. She is not graduated person. When she was young, she has learnt her studies only in the monastery. She is Myanmar and Buddhist. Her race is Bamar. Since she has been to Chaingrai, Thailandfrom Meikhtila, Myanmar, she has worked this job and has not changed to the other works. She is married and has two children. Her husband is also a mason. She and her husband saved the money and supported their family in Myanmar. When she was interviewed, she said as the followings:

"I do not ask what I want to be because everything is ok to work here. Our boss supplied the perfect facilities. We do not have anything to ask for. The wage here is higher than that of Myanmar. But everything is expensive and so we cannot save much money. We have the income daily. The salaries of men are higher than women. Men got 300baht per a day but women got 250 baht. I do not negotiate to pay the salaries as the same to men.We, women in fact cannot work as much as men do. I am satisfied as we are offered and I believe that it is fair. Once my husband and I consulted to change to another job as we are offered smaller wage than the other companies. Sooner, our boss gave us higher salaries than before without being asked. So we do not move. At the work, I don't need to negotiate as all are ok comparing with working in Myanmar. At first we have difficulties due to language biases. Later our boss understands us and always supplies what we need. In this company, only Myanmar people are employed and no Thai workers. So there is no race discrimination and we Myanmar help each other and live as own family. Our work hour is from 8 am to $5 \mathrm{pm}$. We are given break time from $12 \mathrm{pm}$ to $1 \mathrm{pm}$ to have lunch. In our workplace, 
everything is okay and no need to negotiate among each other and between our boss and us although our boss is Thai employer."

From her saying, Daw Thin Gyaing is very satisfied and content what are offered to them by their boss. Most of Myanmar people are content and they are "happy go, lucky people". Although there is gender discrimination, she does not complain. She never negotiates and believes that no need to negotiate at her workplace.

\section{Case (2): Daw (Mrs) Lone Tone}

She is 40 years old. She works in the "Phalaza" construction Co. Ltd in Mae FahLuang University, Chiang Rai. She has been this work for only eight months. She has finished only the primary school. She is not graduated person. Her native town is Chike-Hto, Mon State. In Myanmar she comes from farmer family. She is Myanmar and Buddhist. Her race is Bamar. She is also married and has five children. She cannot support the school fee for her children. So the whole family came to Thailand to work for the money. She does everything she was asked to do as much as she can. Her children and her husband also work in that company. Her family saves the money and solves the debts which owe in Myanmar. From the interview with her:

"We the women don't need to negotiate. We are ok in Thailand more than Myanmar. If we have something difficult, we have to say the head of the workers and she solves all the problems. But there is nothing problem except the language biases. We don't understand Thai language. Our boss supports what we need. We got 220 baht per a day and men got 290 baht per a day. But the workers from the other sites get more money. In Myanmar, we have the cash problems because of the political and economic situations.Here, we don't have to pay the fee of accommodation as the boss solves it for us. Although we have the income daily in Chiang Rai, we have not saved the money as much as we wish because the expense is very high. Everything is ok here. But I love my country and want to return back. When I get the money to solve the debts in Myanmar, I will go back. At the workplace nothing is needed to ask for."

From her point of view, she thinks that everything is ok in Thailand. She wants just only money. And she believes that money makes everything. As she gets money what she needs, she is satisfied what she was offered by the boss. In Myanmar, a worker cannot get as much money as just like that. As Myanmar woman, she does not want to negotiate at the workplace in Thailand.

\section{Case (3): Daw (Mrs) Mon Mon}

Her age is 36 and married. She has one son who is 19 years old. She came from Mogoke , Mandalay Division. She is not able to provide her son's school expense and so she makes her son leave the school and let him to do the job. She has been Thailand for six years. She has been looking for the jobs and works in many industries. Unfortunately, she is not okay and she has to change one job to another for many times. But she did not feel depressed and tried one after to another. Finally she got a job in "Noodle shop" as a waiter and cook. She has not studied well in Myanmar as her parents passed away and she got married when she was too young. She lives together with her family in Chiang Rai, Thailand. The following is from being interviewed:

"I get 250 baht per a day without additional expense. I am very tired of working in the "Noodle Shop". Although my boss told me to start my work from 9 am and finish 7 pm, I usually come to the shop since 7 am in the morning. If I am sick and cannot do my job, my boss cut my salaries. Although my boss suppresses me, my colleagues are good. I need the money to be comfort my family. So I must be patient. Before I got this job, I looked for the jobs in the domestic tasks. But I am unlucky and I am not ok. My boss gives me the salary less than Thai workers. Some of Myanmar workers have lost 
characters so we, Myanmar workers, are suppressed by Thai employers. I feel sorry that as one is not good, all are considered as just like that one. I think that it does not concern with country but individually. For example, if something is stolen, Thai people accused that the thief must be Myanmar. It is not good and illegal. This is just to discriminate. I ask for what I should have. But my boss neglects my demands. I feel content with what she offers me. I have no place to live in and to look for another job. So I am patient and satisfied with what I was offered and I have to be patient in everything. I am afraid that my boss withdraws from her shop. I do not ask more and most of Thai employers looked down that most of Myanmar workers are not educated."

From her interview, the researcher observed that Daw Mon Mon wants to ask more and negotiate. She is a normal worker and so she thinks that she has no chance to ask more and no chance to negotiate. Therefore she is silent and does not even talk. She is worried that she is not as comfortable as working just like that.

\section{Case (4): Daw (Mrs) Khin Aye}

She is 36 years old. She also works in the Phalaza construction Co Ltd in Mae FahLunah University, Chiang Rai. She does the cleaning, painting and tying the fence. She is from ChikeHto, Mon State. In Myanmar, she plants the petal for the business. But petal plantation is not good and less profit for her family. So she and her husband handover the petal plantation business to their parents and left for Thailand to search for the jobs. They took all of their children together with them. The children are adults and they can work. They let the children leave the school and make them to work to solve the family problem. She also passed only the primary school. Her saying was as the following,

"In this company, the head of worker is one of my relatives. She calls us to do in that company. I have nothing to ask for and to negotiate. The head of workers always negotiates on behalf of us. In Myanmar, we are not ok as much as to work in Thailand. The boss supplies all of our needs unnecessary to ask for and to negotiate. Since at the first, we are satisfied what we are offered. But I miss Myanmar and if the political situation changes, I will go back Myanmar. Just now we have no visa. So to get visa, our head helps us with the help of our boss. We have the full security as we are in the university campus. Except missing home country, everything is ok as a worker. We are under control of the head and she managed all of us to be ok."

As a worker, she does not want to ask more for and she does not need to negotiate. She accepts that as she was a worker, it is enough for her that her boss supports her including her family. She was satisfied in the workplace.

\section{Case (5): Daw (Mrs) HtayHtay}

Her age is 40 years. She is also from Mon state. Her race is not Mon but Bamar. She is also married and has one son who is tenth standard. She had been studying until grade five. Although she is not graduated, she wants her son to be graduated and educated. She has been this company for 10 months. Her goal is just to get money to support her son's school fee. So she and her husband work together at the same company, Phalaza Construction Co Ltd. The following shows interviewing with her:

"My son is in the tenth standard student in Myanmar. Our business does not go well with in Myanmar. The expense of tenth standard (Grade 11) student is higher than the other grade students. So I can't afford to support my son. I am not graduated so I have to work roughly. I don't want my son like me. I want him to be educated. I know that I must look for the job to have more money. Working here as a worker is ok for me. At 
the work place, I do as a meson and do the other small works as much as I can. I need money. The boss gives me money we need. So it is ok. No necessary to ask for more and there is no problems at the work place. The head of worker is kind to us and she solves all the things to be ok. I am farmer in Myanmar. Although I do not like this job being as a worker in Thailand, I get more money than in Myanmar. So I will continue this job until I save a lot of money."

She told the researcher about the money problems and she shows mother's love. How try hard she is, she does not care. If she has the problems, she may not ask for and does not negotiate. She is comfortable to be content with what she was given. She was satisfied just to support her son with her wage.

\section{Case (6): Daw (Mrs)Khin Cho}

She is 32 years old. She is also from ChikeHto, Mon State. She has been in "Phalaza" Construction Co Ltd just only 10 months. She is going to move to the same company in Hpuket, Southern Thailand. She has many relatives in that work. She had been studied a little and did not get higher education. She has two sons. Including her two sons, her husband also works at the same company. When she was interviewed, she told the researcher as the following:

"I want my two sons to be educated, but I have no enough money to fulfill my wish. So I withdraw them from the school and work together in the company. I enjoy working there because the whole family is in together and there are many relatives. I am okay in everything. If we have something to ask for and need to negotiate, we need not do directly to the boss. We have to tell our head and she always negotiates between us, the workers and the boss. Although we have some difficulties, it is inconsiderably in comparing with Myanmar. We have nothing special to ask for and to negotiate. The boss gives us the wages as the same to Thai workers. There is no discrimination between Myanmar workers and Thai workers. It is ok for me as we have the money we need although we are not happy to stay in Thailand. I want to go back Myanmar. I support my family in Myanmar with the money I save here. I work any job as necessary. After I have saved money, I want to go back Myanmar. But in Myanmar, our business is not ok and we will not get money as much as I get here. At our workplace, our boss fulfills our wish and gives the rights which a worker should have. So we do not need to ask for more. We should know we are workers and women. It is not suitable to ask for more than the chance that a worker should have."

From being interviewed, Daw Khin Cho is uneducated but she has the ethics. She considered bothsides of the boss (employer) and the workers. As an employer, he has the responsibilities to fulfill the employee's wish, vice versa, as the worker, she does not ask for more than what she should have.

\section{Case (7): Daw (Mrs) May 0o}

Mrs May Oo is 38 years old. She is married and has two children. She is from Meikhtila, Myanmar. Her elder daughter who is 10 years old is left with her grandmother in Myanmar. Together with her, her younger daughter who is two years old and her husband are in Thailand. She is meson and does her husband also. She saves money to support her daughter and her mother in Myanmar. She is not educated and she does not want her children to be as a worker like her. So after working in Chiang Rai, Thailand, as a meson in the "Phu" construction Co Ltd, she saves money to solve the problems of her children's school expense. She has been that company for three years. She speaks out as the followings while interviewing her:

"Everything working here is very comfortable comparing with Myanmar. I want to support my children to be educated persons. I don't want to call my daughters to 
Thailand because I want them to live in Myanmar. I am uneducated so I work as a slave in another country. I get 220 baht per a day. At the previous time, I got more money than at the present time. But we do not complain about that and we do not negotiate at all. We understand that our boss has some problems and so he cannot give money as much as before. We don't want to ask for any more. When he was ok in his company, he supported us as much as he could. We know that he wants to give us more money. Anyway, we are satisfied with what we are offered. I save the money I got from working as a worker in the bank and support my daughter's school expense. I feel sorry when I see Myanmar children workers. I have taken "opt-out" times during my working period when I gave birth to my younger daughter. During my "opt-times", I have not got any income. It is ok at the work place. So I don't need to ask for more and no problem that I need to negotiate"

Daw May Oo wants to support her daughters' school expense. As she has got enough money to be able to provide her family, she is satisfied with her job at the work place. She seems to admire her boss and she doesn't ask for more even when her boss gave the workers less money than before. She shows sympathy to her boss.

\section{Case (8): Ma (Ms) Tin TinNaing}

She is 32 years old. She has been in Thailand for 12 years. At first she has been Bhuket for 10 years. In ChaingRai she has worked for two years. Now she works in the "Phalaza" Construction Co Ltd. She is from Malockchaun Village, KyaikHto, Mon state. She has studied the higher education. She has been struggling for along time and encountered many difficulties. At the workplace, she is the head of Myanmar workers. She is single and is loved and respected by all Myanmar workers on the other hand, she is trusted by her boss. She solves all the problems of the workers in social affairs and health. In the last two years, she returned to Myanmar because she felt so sorry that Myanmar three workers were killed in her workplace. But she has to come back Thailand as her boss called her back to lead Myanmar workers. She proposed her boss to employ the relatives from her villages in Myanmar. As she is single, she always concentrates on the workers' affairs.From the following interview with her, it is observed that she is a successful negotiator between the workers and the boss.

"In the workplace, there are a lot of my relatives from my village. I told my boss to employ them at his company. At the workplace there is no discrimination between my relatives and the strangers. But outside the work, I treat them warmly. As a good leader, I have to make the good decision. I have got 30000 baht per a month. Although the salary is good, I do not enjoy in staying the other country. I am Myanmar and so I love Myanmar. I want to go back our country. But, I am not okay to do business in Myanmar. So due to situation, I have been working Thailand. I do not let Myanmar female workers to meet directly with the Thai people and Thai employers. I ask for the boss what they need on behalf of the workers. My boss is very kind and good-hearted. He fulfills what the workers want to be. The workers rely on me and my boss believes me. He likes Myanmar's labor than Thai's labor. I do not misuse my boss's belief. I cannot speak Thai language well. But I prove his belief with my work done. I have to observe everything because I am interested in my job. As a leader, I must be talkative. If the workers have the problems and the difficulties, I have to meet the boss and have to tell what the workers want to be. Our boss solved the difficulties.

We, the workers, need the money and the boss needs our labour. So the boss gives us the money what we need and we also give him the labour that is needed for his company. I have to ask for the wage of female per a day from 200 to 220. It is successful to negotiate and the boss increase to 220 baht per a day. I always read the 
current news. Only when I know what happens in the world, I can know how I handle my job. Even the Thai engineers in Thailand make the mistakes in measuring for the building. For me just to seeI can guess how long and how much the measuring is. I think that skill and experience are also needed to be expert in the job. I donated the money that I got from working to the necessary places. Although there are a few language biases between my boss and me, I can solve all the problems with my work done. So my boss loves me very much, he fulfills the workers' need. As for me, I negotiate what the boss can, not negotiate what the boss can't. So far so good. As you know that we Myanmar people are religious and we always follow the Buddha's rule. We are not aggressive and I have to see both sides. I want both my boss and Myanmar workers to be ok in both sides. Fortunately, most of Myanmar people are content and satisfied with to live in normal life. I often do negotiate between the boss and the workers and usually most of negotiations are successful. I have the responsibilities to save Myanmar women workers' life."

As my point of view, Ma Tin Tin Naing is a good negotiator. She is the good assistant for her boss and the dutiful leader for Myanmar workers. From being interviewed, she pointed out that to be a good negotiator; the skill, experience and knowledge which are negotiation competences are needed. Ma Tin TinNaing has the negotiation competence to negotiate. The researcher noticed that as she has these abilities, her negotiations are agreeable and both parties are satisfied and she is loved and admired by both sides. Her boss did not want to lose a good assistant like her and is worried that she will go back Myanmar.

\section{Case (9): Ma (Ms) May Thet Hnin}

She is 21 years old. She is from Saehto village, Mandalay division. She works as a waiter in "My Mom" food and drink shop in Chiang Rai, Thailand. She is very active and serves everyone with smile. She has been in this shop for two years. Before working in that shop, she had worked in the construction in Thailand as a meson for nine months. She has studied until Grade 8. She is single and she came to Thailand with her elder sister to find the job since the last about three years. Her sister works as meson in "Phu" Construction Co Ltd. She works as a waiter and provides her two younger brothers who have been living in Myanmar. Although she is young, she seems to be expert in her job and matured. The followings are noted from her words:

"I enjoy my job in this shop as a waiter. My parents passed away when we were young. So we cannot survive in our village in Myanmar. I need to support my two younger brothers for their school expense and so I left the school and left for Thailand together with my elder sisters to find the job. I need money to stand for our lives. Before working here, I had to work as a meson in the construction. After working for nine months in the construction company, I moved to that job. Because the wage of a meson is just 200 per a day and the salary here is higher and I get 300 baht per a day without additional expense. The owner of the food and drink shop is very kind and helpful. She loves me as her own daughter. Everything is ok. I can also speak in Thai language. I work in the shop from 9(a.m.) in the morning to 9(p.m.) in the evening. Sometimes, I start my job from 7 am and finished 10: 30 p.m. However, the owner gives me the money as I need to be enough. I am satisfied and I have no more to ask for. If I have some problems, she can solve immediately. As I have been here for two years, I can work everything whatever I am asked. But I want to go back Myanmar. After I have saved money, I will go back Myanmar and I will do some business for family survival."

She is young and satisfied with everything. She does not want to ask for more and to negotiate. Her goal is to get money and to be ok in accommodation and her food. According to her words, her owner fulfills what she needs and she thinks that her life is full. As she was one of the 
orphans, she may want the warmth and love from something. She feels the kindness and loves of her owner and gets the money that fulfills her life. So she does not mind to ask for more and no need to negotiate.

\section{Case (10): Ma (Ms) Ei Ei Thaw}

She is 25 years old and she is single. Although she is not graduated, she has studied higher education. She is Shan race and Buddhist. She can speak Thai and English. Her native town is Mogoke, Mandalay division, Myanmar. She has been struggling in her life. Both her father and her mother passed away when she was young. Just now she lives with her elder sister in Chiang Rai, Thailand. No sooner did she arrive in Chiang Rai than she sold the flowers to survive. Later she moved to "coffee shop" to make the coffee. She has worked in that coffee shop for three years. When the researcher interviews her, she replies just like the following:

"At first, my boss looked me down as I am Myanmar. Most of Thai people suppress Myanmar people because of the historical background. But I was patient and worked harder and harder. Later, she loves me as her own daughter. She gives me 200 baht per a day and I have to work from 9 am to 3:30 pm. She provides what I need. She does not cut my salary down for the holidays. I am a lucky girl to get a good job despite of the low salary because the other Myanmar workers have to face many difficulties. My boss fulfills most of the demands and I don't want to negotiate anything as I am a worker. But there is something to ask for necessarily in my life. I have to be satisfied what I was offered. In Myanmar, I do not earn as much as what I get in Thailand. So I am satisfied. The longer I live here, the more expert in my work and the more my owner understands me. So just now I have been here for three years and I enjoy it. I want to come back Myanmar, but in Mynamar I have no parents and I have decided to stay here as long as I can."

She has been facing the suffering in her life. So she feels satisfied in her present job and does not ask more. But she asks what she really needs, because of her hard work and polite behavior, her boss fulfills most of her demands. She only asks and negotiates the small things that her boss can afford. She did not dare to negotiate and ask for more as she is afraid to withdraw her job.

This study was intended to distribute how the women workers negotiate at their workplace. All of the women in this study indicated that they were hardworking and committed on their works, most of the women in this study were workers and they satisfied with they were offered. They asked for only what their boss can give them. Most of them do not want to negotiate more as in their mind they feel despair that they are workers.

Based on the interviewing with the participants, the researcher presents in four areas due to Weaver, D.E. (2011): (1) women's reluctance to speak up on their own behalf (2) their attitudes negotiating (3) their strategies to negotiate in the workplace and (4) women's anxieties and fears over the potential for the people's response..

(1) Women's reluctance to negotiate

In this study, women's anxieties about negotiating seem to be ingrained and seem to impact women's handling important situations in the work place. Although all of the participants reported facing important situations where they needed to negotiate on their own behalf, most of the women were not willing to do so, especially early in their careers. Most of the participants knew that they should speak up and negotiate on their own behalf, they may be avoiding negotiations that could help them. 
(2) Women's attitudes about negotiation

Some women do not believe they need to change how they negotiate. Participants who showed an attitudes and motivation to engage in a deliberate process to gain skills and improve at speaking up and negotiating were the individuals whose behaviors changed overtime. Women who improve at speaking and negotiating on their own behalf have attitudes and motivation that support the learning process.

(3) Women's strategies

Women seem to speak by seeking multiple ways to collect information and to build a flexible repertoire of behaviors. Women gain skills and confidence about negotiating by using a wide range of factors such as experiences, input and support from other individuals, reflection and education.

(4) Women's anxieties and fears over the potential response

Women who gain negotiation competence are better prepared to handle situations strategically that might result in the discrimination. Some women prefer not to speak up or to speak up in gender appropriate ways. Women need a better understanding of the realities of the potential repercussion in their workplaces. The researcher noticed that women who gain skills, knowledge and the attitudes of negotiation competence will be better prepared to ask for what they need and deserve in the workplace.

\section{FINDING AND DISCUSSION}

From interviewing with the Myanmar female workers, Table 1 shows that except Ms. Tin Tin Naing, no one wants to ask more and negotiate.

Table 1. The participants who negotiate and who do not negotiate

\begin{tabular}{|c|c|c|c|}
\hline \multirow[b]{2}{*}{ Sr No } & \multirow[b]{2}{*}{ Name } & \multicolumn{2}{|c|}{ Negotiation } \\
\hline & & Yes $(\hat{\mathrm{A}})$ & No (â) \\
\hline 1 & Mrs Thinn Gyaing & & â \\
\hline 2 & Mrs Lone Tone & & $\hat{a}$ \\
\hline 3 & Mrs Mon Mon & & â \\
\hline 4 & Mrs Khin Aye & & $\hat{a}$ \\
\hline 5 & Mrs HtayHtay & & $\hat{a}$ \\
\hline 6 & Mrs Khin Cho & & $\hat{a}$ \\
\hline 7 & Mrs May Oo & & â \\
\hline 8 & Ms Tin Tin Naing & $\hat{A}$ & \\
\hline 9 & Ms May Thet Hnin & & $\hat{a}$ \\
\hline 10 & Ms Ei Ei Thaw & & $\hat{a}$ \\
\hline
\end{tabular}


Figure 1 shows that according to the present survey, the percentage of non negotiation is 9 times higher than that of negotiation.

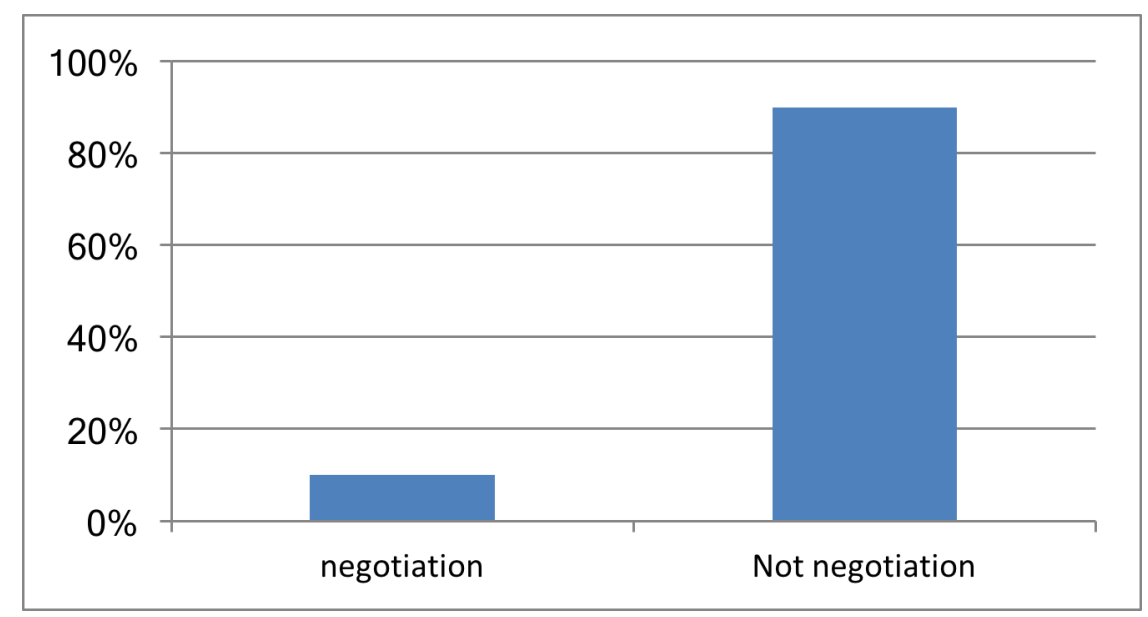

Figure 2. Percentage of female workers who negotiated and do not negotiate

Due to the data mentioned, as female migrants from Myanmar, theses women have to work as low-status laborers as domestics workers and mesons in building construction. Among the 10 participants, it is found that only Ms Tin Tin Naing asks for more and negotiates on behalf of the workers. Most of her negotiations are successful. She is higher status than the other workers as she is the leader of Myanmar workers at the workplace. Moreover she has the power over and influent to the workers. It is observed from being interviewed, she has the negotiation competence: skill, knowledge and experience. From this study, only $10 \%$ of female workers ask for more and negotiate and about $90 \%$ of female workers do not ask and negotiate at all as some were satisfied with their jobs as their head solved their problems on behalf of them and some were lack of confidence.

\section{CONCLUSION}

Women who seek equitable treatment need to speak up, negotiate and demand their rights. The reason that no more progress have been made toward equality for women in the workplaces and homes and so many women are silent when they need to demand their rights is their lack of willingness to negotiate ( Sara Laschever 2003 cited in Weaver, D.E. 2011) . Women should negotiate regularly to defend their rights and speak out against unfairness.

In the present study, it is found that most of the women do not ask for and they do not negotiate because they think that they are low status workers and they have no confidence to negotiate. The women are weak, emotional and submissive so they might not be successful negotiators. Although men and women work the same job at the same workplace, men get higher salaries than men. From this study, it can be observed that Myanmar women workers are not aggressive and have sympathy. They always consider their boss and their owner. As they are workers, they have no confidence to ask and were satisfied with their current jobs in comparing with Myanmar in which they have economic problems. 


\section{References}

Chantavanich, S., Myanmar Migrants to Thailand and Implications to Myanmar Development, BUSINESS, Union of Myanmar Federation of Chambers of Commers \& Industry on, 2012.13 (1):

Doncha-um.D., Burmese Migrant Workers: Tactics of Negotiation among Domestic Workers in Chang Klan Community ed 2008, (Thailand).

Hedstrom. J . Negotiations for Peace in Burma, ed 2013, in The Swedish Burma Committee

Paddock, E. L., \& Kray, L. J., The role of gender in negotiation. In Benoliel, M (Eds.), Negotiation excellence: successful deal making, 2011: World Scientific Publishing Co. Pte. Ltd on, 2011. (Singapore) P. 229-245

Weaver, D.E., How professional women learn to speak up and negotiate for themselves in the workplace (Doctoral dissertation, Education in Teachers College). Pro Quest Dissertation and Theses database on, 2011 .(UMI No, 348) 